Paper to be published in Proceedings of International Composites Expo '98 (ICE "98), Nashville, Tennessee, January 19-21, 1998

\title{
CREEP AND CREEP-RUPTURE BEHAVIOR OF A CONTINUOUS STRAND, SWIRL MAT REINFORCED POLYMER COMPOSITE IN AUTOMOTIVE ENVIRONMENTS*
}

\author{
W. Ren ${ }^{\dagger}$ and C. R. Brinkman \\ Metals and Ceramics Division \\ $x$ \\ OAK RIDGE NATIONAL LABORATORY \\ P.O. Box 2008 \\ Oak Ridge, TN 37831-6155
}

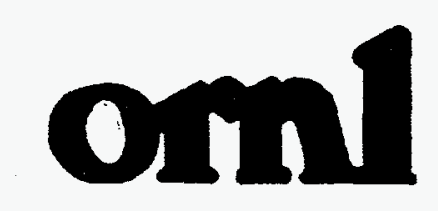

${ }^{*}$ Research sponsored by the U.S. Department of Energy, Assistant Secretary for Energy Efficiency and Renewable Energy, Office of Transportation Technologies, as part of the Advanced Automotive Materials Program, under contract DE-AC05-960R22464 with Lockheed Martin Energy Research Corporation.

†Postdoctoral Researcher.

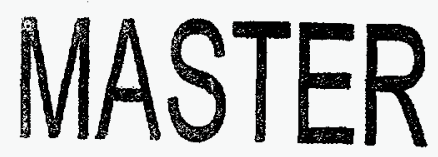

The submitted manuscript has been authored by
a contractor of the U.S. Government under
contract No. DE-ACO5-96OR22464. Accordingh.
the U.S. Government retains a nonexclusive,
royalty-free license to publish or reproduce the
published lorm of this contribution, or allow others
to do so, for U.S. Govemment purposes. 


\section{DISCLAIMER}

This report was prepared as an account of work sponsored by an agency of the United States Government. Neither the United States Government nor any agency thereof, nor any of their employees, make any warranty, express or implied, or assumes any legal liability or responsibitity for the accuracy, completeness, or usefulness of any information, apparatus, product, or process disclosed, or represents that its use would not infringe privately owned rights. Reference herein to any specific commercial product, process, or service by trade name, trademark, manufacturer, or otherwise does not necessarily constitute or imply its endorsement, recommendation, or favoring by the United States Government or any agency thereof. The views and opinions of authors expressed herein do not necessarily state or reflect those of the United States Government or any agency thereof. 


\section{DISCLAMrER}

Portions of this dosament msy be illegible in electronic image prodnets. Imoges are produced from the best available origion documenter. 


\section{ABSTRACT}

Creep and creep-rupture behavior of an isocyanurate based polyurethane matrix with a continuous strand, swirl mat E-glass reinforcement was investigated for automotive applications. The material under stress was exposed to various automobile service environments. Results show that environment has substantial effects on its creep and creep-rupture properties. Proposed design guide lines and stress reduction factors were developed for various automotive environments.

\section{INTRODUCTION}

Glass swirl mat reinforced polymer matrix composites are considered candidate structural materials for light weight and fuel efficient automobiles of the future [1-3]. Potential applications of these materials include floor pans, body side frames, crossmembers, and front structural members. Despite their potential, a question that must be addressed before they will be widely used is their known durability. Answering this question is one of the key goals of the Automotive Composites Consortium [4]. During their service lives of approximately 15 years, automobile structures will be subjected to creep resulting from sustaining stresses plus cyclic loadings from motor vibration, acceleration, deceleration, turning and rough roadway conditions, exposed to a variety of environments such as temperature and humidity changes, water and salt contacts, various automotive fluids including windshield washer fluid, battery acid, antifreeze coolant, brake fluid and motor oil. These factors could individually or synergistically produce damage to the components. The present study, as a part of the efforts to address the durability issues, is to investigate the effects these factors may have on dimensional stability and strength of the composite structure throughout the required life, and also develop experimentally-based, durability driven design guidelines for automotive composite structures.

\section{EXPERIMENTAL PROCEDURES}

\section{MATERIAL}

The material studied was a structural reaction injection molded isocyanurate based polyurethane matrix with a continuous strand, swirl mat E-glass reinforcement. The 
matrix consisted of an isocyanate and a polyol. Tensile strength of the matrix without reinforcement was $70.3 \mathrm{MPa}(10.2 \mathrm{ksi})$. The continuous strand swirl mat was made of standard $E$ glass strands consisting of several hundred $19 \mu \mathrm{m}(0.0007$ in.) diameter monofilaments. The filaments had a strength of $1722.5 \mathrm{MPa}(250 \mathrm{ksi})$ and a modulus of $68.9 \mathrm{GPa}\left(10 \times 10^{3} \mathrm{ksi}\right)$. Sizing ( $<0.5 \%$ by weight) was applied to improve adhesion to the matrix and binder was employed to hold the mat together ( $8 \%$ by weight). The mat was transversely isotropic to within $20 \%$. Five layers of mat were used in the $3.175 \mathrm{~mm}(0.125$ in.) thick isocyanurate plaques. Measurements indicated that the fiber content of the plaques was about $55 \%$ by weight and the void content about $14 \%$ by volume.

\section{TEST MATRIX}

The test matrix was designed to simulate possible service conditions for an automobile. The baseline condition considered was $24^{\circ} \mathrm{C}\left(75^{\circ} \mathrm{F}\right)$ in air $50 \%$ relative humidity (air $=50 \% \mathrm{RH}$ ). The other service conditions included cold and hot weather, engine operation heat, dry air in desert and dannp air in coastland, exposure to water in a rain or car wash, spill of coolant, windshield fluid, brake fluid, motor oil and battery, acid, motor vibration and low frequency load cycling on a rough road. The material was tested in these simulated conditions at various stresses ranging from 17 to $138 \mathrm{MPa}$ ( 2.5 to $20 \mathrm{ksi}$ ) in tension, and some in compression for comparison. The test matrix was developed gradually from the baseline condition as the completed tests showed whether testing in a further extreme condition was necessary. For example, when completed tests showed decreasing temperature to $-7^{\circ} \mathrm{C}\left(-20^{\circ} \mathrm{F}\right)$ in air $=50 \% \mathrm{RH}$ actually increased creep strength, further decrease of testing temperature to $-40^{\circ} \mathrm{C}\left(-40^{\circ} \mathrm{F}\right)$, although a possible service condition, was considered reasonably unnecessary. The complete testing conditions at various stresses are listed as follows:

1. Air $=50 \% \mathrm{RH}$ at $-7,24,57,88$ and $121^{\circ} \mathrm{C}\left(-20,75,135,190\right.$ and $\left.250^{\circ} \mathrm{F}\right)$.

2. Air $<10 \% \mathrm{RH}$ and air $>90 \% \mathrm{RH}$ at $24^{\circ} \mathrm{C}\left(75^{\circ} \mathrm{F}\right)$.

3. Water at 24,57 and $88^{\circ} \mathrm{C}\left(75,135\right.$ and $\left.190^{\circ} \mathrm{F}\right)$.

4. Water-based fluids: anti-freeze coolant (50vol.\% Water $+50 \mathrm{vol} . \%$ Ethylene Glycol Base Anti Freeze-Texaco, Anti-Freeze Coolant, Texaco Lubricants Co.) at $-15,-12,3$ and $24^{\circ} \mathrm{C}\left(5,10,27\right.$ and $\left.75^{\circ} \mathrm{F}\right)$, salt water (saturated solution at room temperature) and windshield washing fluid (Krystal Kleer Windshield Washer Solvent, South Win, Ltd.) at $24^{\circ} \mathrm{C}\left(75^{\circ} \mathrm{F}\right)$.

5. Oil-based fluids: brake fluid (Western Auto Super Heavy Duty Stop Rite, Brake Fluid for Drum or Disc Brakes, Western Auto Supply Co.) and used motor oil at $24^{\circ} \mathrm{C}\left(75^{\circ} \mathrm{F}\right)$.

6. Sulfuric acid $(35 \mathrm{wt} \%)$ immersion or splatter at $24^{\circ} \mathrm{C}\left(75^{\circ} \mathrm{F}\right)$.

7. Compression in air $/ 50 \% \mathrm{RH}$ and water at $24^{\circ} \mathrm{C}\left(75^{\circ} \mathrm{F}\right)$, in water at $57^{\circ} \mathrm{C}\left(135^{\circ} \mathrm{F}\right)$.

8. Motor vibration in air $=50 \% \mathrm{RH}$ at $24^{\circ} \mathrm{C}\left(75^{\circ} \mathrm{F}\right)$. Vibration frequency $=2000$ cycles per minute, vibration strain range $=5.08 \mathrm{~mm}$ ( 200 microinches).

9. Low frequency load cycling in air $=50 \% \mathrm{RH}$ and water at $24^{\circ} \mathrm{C}\left(75^{\circ} \mathrm{F}\right)$. Cycling frequency $=30$ cycles per minute. Stress ratio $\left(\sigma_{\min } / \sigma_{\max }\right)=0.3-0.4$.

Totally, 318 tests have been conducted in this investigation.

\section{TEST PROCEDURES}

The nominal size for tensile creep specimen was $203.2 \times 25.4 \times 3.18 \mathrm{~mm}(8 \times 1$ $x 0.125$ in.). Both ends of the specimen were reinforced with bonded $G-10$ tabs over a length of $50.4 \mathrm{~mm}$ ( 2 in.) and the active gage length was $101.6 \mathrm{~mm}(4 \mathrm{in}$.). The nominal size for compressive creep specimen was $31.75 \times 25.4 \times 3.18 \mathrm{~mm}(1.25 \times 1$ 
$x 0.125 \mathrm{in}$.) with no reinforcing tabs. The shortened length was to prevent buckling, and both ends of the specimen were machined parallel to each other to ensure uniform stress distribution when compressed.

The tests were conducted using lever arm creep machines. Reliable and inexpensive grips were developed to hold the specimens during creep testing. For tensile loading, the specimen was held by two $38.1 \mathrm{~mm}$ (1.5 in.) long segments of a curved tooth file, which were backed by pieces of stainless steel plate with slots to limit the travel of the file segment. Four screws were torqued to a set value to hold these components together firmly. The stainless steel pieces were attached to the rest of the pull stringer with steel pins. For compressive loading, each end of the specimen was inserted into a slot $6.35 \mathrm{~mm}(0.25 \mathrm{in}$.) deep that fitted the sample snugly in a piece of stainless steel of $25.4 \times 25.4 \times 9.53 \mathrm{~mm}(1 \times 1 \times 0.375 \mathrm{in}$.). The two stainless steel pieces fitted against two parallel blocks. The bottom block was attached to the top pull rod and the top block to the bottom pull rod to produce a compressive load on the specimen.

Strain was measured using type CEA-13-SOOUW-350 strain gages with a measuring section $12.7 \mathrm{~mm}(0.5 \mathrm{in}$.) long manufactured by the Measurements Group, Inc. The gages were bonded with M-bond 200 and protected by a wax coating when tested in fluids at and below $57^{\circ} \mathrm{C}\left(135^{\circ} \mathrm{F}\right)$, with M-bond GA-61 and protected by a coating of Dow Corning 3145 RTV adhesive/sealant when tested in fluids at and above $88^{\circ} \mathrm{C}\left(190^{\circ} \mathrm{F}\right)$.

For air $=50 \% \mathrm{RH}$ at and above $57^{\circ} \mathrm{C}\left(135^{\circ} \mathrm{F}\right)$, the specimen was heated using heating tapes. Pieces of copper sheet of $101.6 \times 25.4 \times 3.18 \mathrm{~mm}(4 \times 1 \times 0.125$ in.) were placed on each side of the specimen gage length to ensure uniform heating. Thermocouples were attached to the gage length using glass tape. The heating tape was wound over these materials and insulated with insulation cloth.

For air $<10 \% \mathrm{RH}$ and air $>90 \% \mathrm{RH}$, the specimen was tested in an environmental chamber with air of the respective humidities flowing through.

For water at 24,57 and $88^{\circ} \mathrm{C}\left(75,135\right.$ and $\left.190^{\circ} \mathrm{F}\right)$, the specimen was immersed in distilled water. The desired temperature was kept constant and uniform throughout the chamber with an immersion heater and thermocouples plus an electrical stirrer. To compensate for evaporation, a reliable and inexpensive water level adjusting system was developed. The system simply consisted of a plastic jar with a hermetical lid on top and a flexible tube in bottom. The jar was filled with water and placed above the specimen chamber with its lid sealed air-tight and tube outlet immersed below the water level in the chamber. When the water level decreased to expose the tube outlet, air would get into the jar through the tube and release jar water into the chamber until the water level rose to seal the outlet again and no air could get into the jar.

For water- and oil-based fluids, electrical stirrers were employed when thought necessary to keep the fluids uniform.

For tests below $24^{\circ} \mathrm{C}\left(75^{\circ} \mathrm{F}\right)$, the specimen was inserted into a cooling coil with cooled ethylene glycol/water solution pumped through from a refrigeration unit. The air or fluid in the insulated specimen chamber was cooled by the coil to keep the specimen at the desired low temperature.

For sulfuric acid exposure, the immersion test was conducted with the specimen inserted in a glass tube of the specimen gage length, and the gap between the specimen and the tube at the bottom was sealed with bath tub sealant so that sulfuric acid could be contained. In the splatter test, about $3 \mathrm{cc}$ of acid solution was placed on the surface of a virgin specimen. The specimen was then heated for 24 hours at $65.6^{\circ} \mathrm{C}\left(150^{\circ} \mathrm{F}\right)$ so that absorption occurred. The sample was then tested in air $=50 \% \mathrm{RH}$ at $24^{\circ} \mathrm{C}\left(75^{\circ} \mathrm{F}\right)$.

For motor vibration, the vibration was introduced by attaching to the fixed load a motor that ran with an eccentric cam on its shaft. For low frequency load cycling, the 


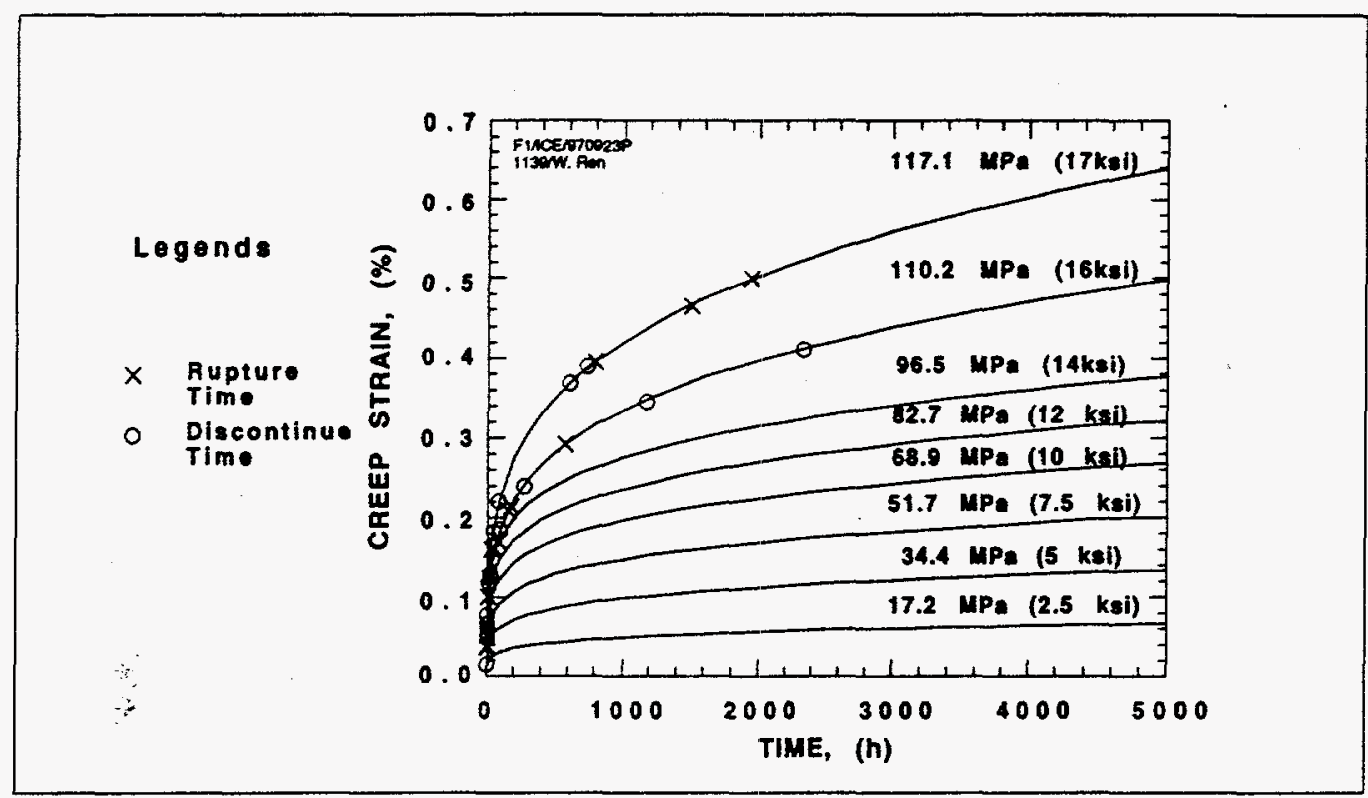

Figure 1.. Representative creep curves derived from experimental data show that creep strain increases linearly with stress below $96.5 \mathrm{MPa}(14 \mathrm{ksi})$ in air $=50 \% \mathrm{RH}$ at $24^{\circ} \mathrm{C}\left(75^{\circ} \mathrm{F}\right)$.

cycling was produced by an air-driven piston that added a pulsing load to the fixed load.

All the tests were loaded at a rate of about $2.5 \% / \mathrm{min}$. The first 24 hours of the deformation including loading deformation was continuously recorded as a function of time using a chart recorder. The loading strain was determined from the chart with a maximum error of $0.04 \%$ and subtracted from the total strain. Only the timedependent portion of the total strain was used for plotting a creep curve.

\section{RESULTS AND DISCUSSION}

Factors that affect the durability of the material can be categorized as stress, temperature, humidity, fluid, load variation and tension/compression.

The stress effects are demonstrated in Figure 1 by representative creep curves derived from experimental data in air $=50 \% \mathrm{RH}$ at $24^{\circ} \mathrm{C}\left(75^{\circ} \mathrm{F}\right)$. These curves show a characteristic high initial creep rate followed by a significant decrease, especially at low stresses, to near zero. Below 96.5 MPa (14 ksi), creep strain, $\varepsilon(\%)$, is proportional to stress, $\sigma(\mathrm{MPa})$, at a given time, $\mathrm{t}(\mathrm{h})$, and can be described by [5]:

$$
\varepsilon=7.36 \times 10^{-4} \cdot \sigma \cdot t^{0.196}
$$

Note the " $x$ " and "o" symbols, all on curves above $82.7 \mathrm{MPa}(12 \mathrm{ksi})$, only indicate the time at which samples were ruptured or tests discontinued respectively. They do not imply that the actual ruptured and discontinued curves perfectly match the representative curves. Figure 1 shows a dependence on stress with creep being more rapid and the failure time shorter as the tests were run at progressively higher stresses. In all tests, fracture occurred without obvious acceleration of the creep rate or local necking. Significant data scatter was observed. 


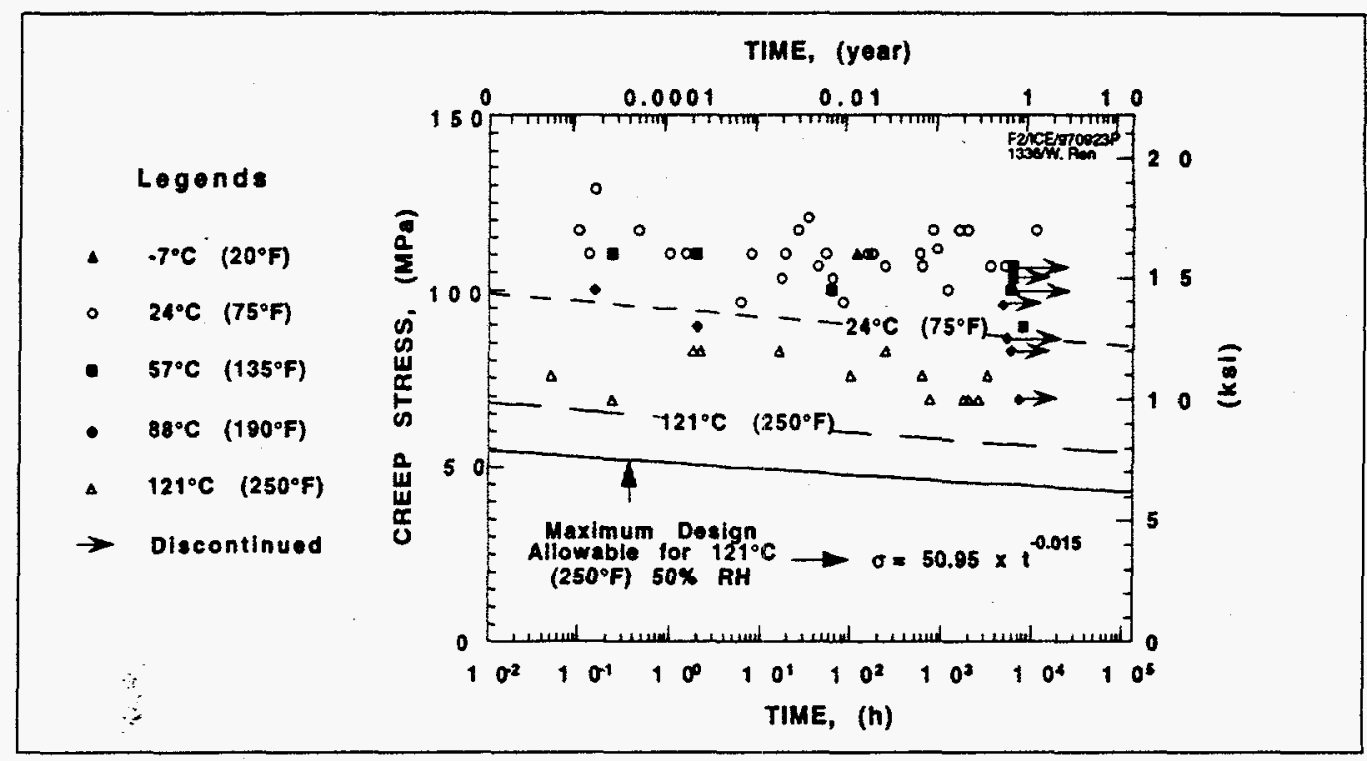

Figure 2. Increase in temperature decreases the creep-rupture stress. $\therefore$

Temperature effects were observed from tests in various environments including air $=50 \% \mathrm{RH}$ at $-7,24,57,88$ and $121^{\circ} \mathrm{C}\left(-20,75,135,190\right.$ and $\left.250^{\circ} \mathrm{F}\right)$, water at 24,57 and $88^{\circ} \mathrm{C}\left(75,135\right.$ and $\left.190^{\circ} \mathrm{F}\right)$ and anti-freeze coolant at $-15,-12,3$ and $24^{\circ} \mathrm{C}$ $\left(5,10,27\right.$ and $\left.75^{\circ} \mathrm{F}\right)$. All these data show that an increase in temperature decreases creep strength and rupture time. Figure 2 gives a typical plot showing the temperature effects in air $=50 \% \mathrm{RH}$. Although significant data scatter exists, the general trend that

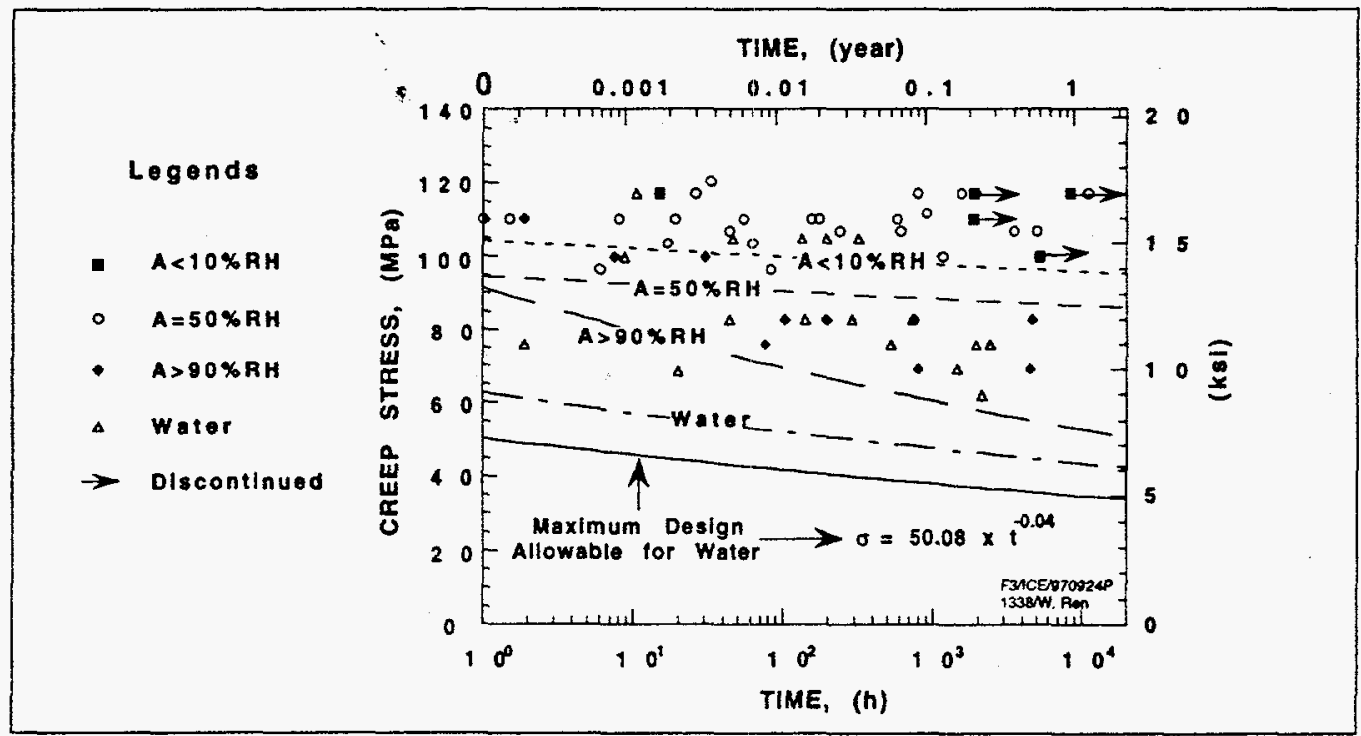

Figure 3. Increase in humidity significantly decreases creep-rupture stress. 


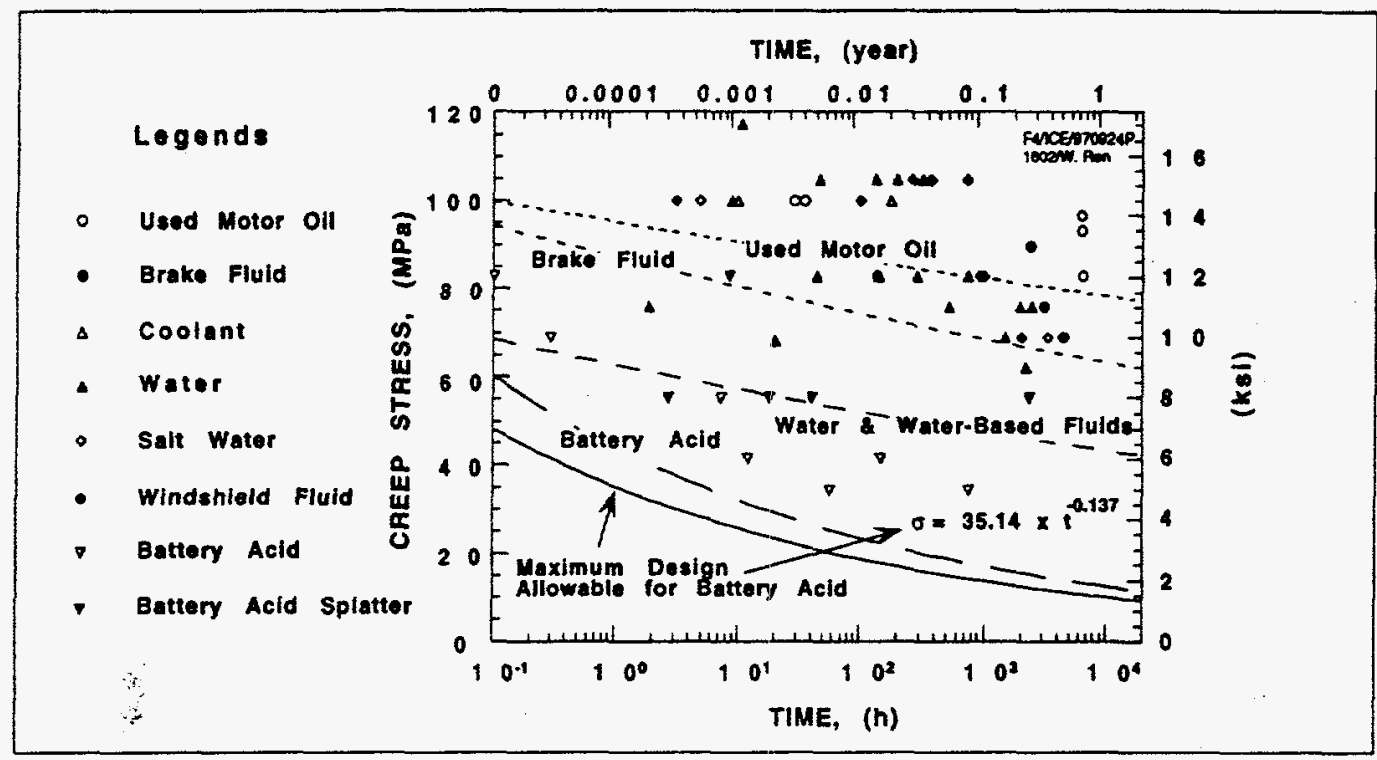

Figure 4. Creep-rupture stress is reduced by oil- and water-based fluids, but most - severely by battery acid splatter as well as immersion.

creep rupture stress decreases as temperature increases is apparent, indicating a decrease in creep strength and rupture time. To develop a design guideline for the material, curves representing the highest stresses that may not cause rupture (norupture) were derived based on a least-squares fit of the respective data, given in Figure 2 as dash lines. The proposed maximum design allowable stress curve, which is the design guideline in consideration of creep-rupture, was obtained by multiplying the no-rupture line for $121^{\circ} \mathrm{C}\left(250^{\circ} \mathrm{F}\right)$ by a safety factor of 0.8 . Since $121^{\circ} \mathrm{C}\left(250^{\circ} \mathrm{F}\right)$ represents the extreme service temperature for the automotive components previously described, the proposed maximum design allowable stress curve is believed to cover all the normal service temperatures in air $=50 \% \mathrm{RH}$ for the automotive applications of the material. To further facilitate engineering design, the equation for the proposed maximum design allowàble stress curve is also developed as presented in Figure 2 . If necessary, maximum design allowable stress curves and equations for other temperatures can also be obtained with the same method.

Humidity effects are given in Figure 3, which shows that at $24^{\circ} \mathrm{C}\left(75^{\circ} \mathrm{F}\right)$ creeprupture stress decreases as humidity increases in an order of air $<10 \% \mathrm{RH},=50 \% \mathrm{RH}$, $>90 \% \mathrm{RH}$ and water immersion, indicating a decrease in creep strength and rupture time. Again, the dash lines represent the no-rupture stresses. To develop the proposed maximum design allowable stress curve and equation for possible humidity service conditions, the no-rupture line for the extreme case, water immersion, was selected and multiplied by a safety factor of 0.8 .

Fluid effects are shown in Figure 4, which indicates that in all the fluids at $24^{\circ} \mathrm{C}$ $\left(75^{\circ} \mathrm{F}\right)$, creep-rupture stress decreases in an order of oil-based fluids (used motor oil and brake fluid), water and water-based fluids (salt water, windshield fluid and antifreeze coolant) and battery acid (immerse and splatter). Battery acid splatter has similarly severe damaging effects as the immersion. Since the splatter is a likely case for automobiles, precautions such as corrosion resistant coatings are suggested if the material is employed for components near the battery.

Load variation effects are presented in Figure 5 showing data from static loading, motor vibration and low frequency load cycling tests in air $=50 \% \mathrm{RH}$ at $24^{\circ} \mathrm{C}\left(75^{\circ} \mathrm{F}\right)$. 


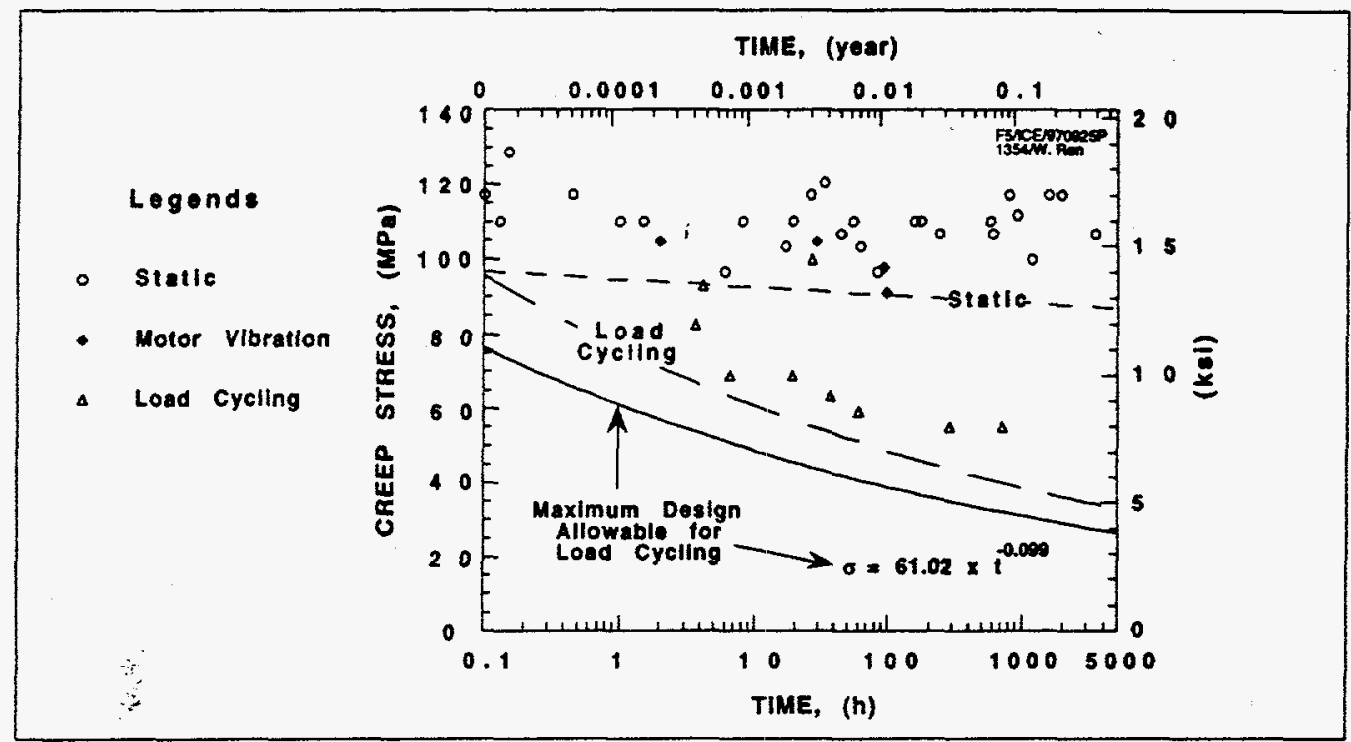

Figure 5. Creep-rupture stress is reduced slightly by motor vibration but - significantly by low frequency load cycling.

The results indicate that compared to static loading, motor vibration has a little effect on creep strength and rupture time while load cycling significantly reduces these properties. This suggests that acceleration, deceleration and rough roadway conditions can be more damaging than motor vibration to this material. Precautions should be considered when the material is directly exposed to these conditions.

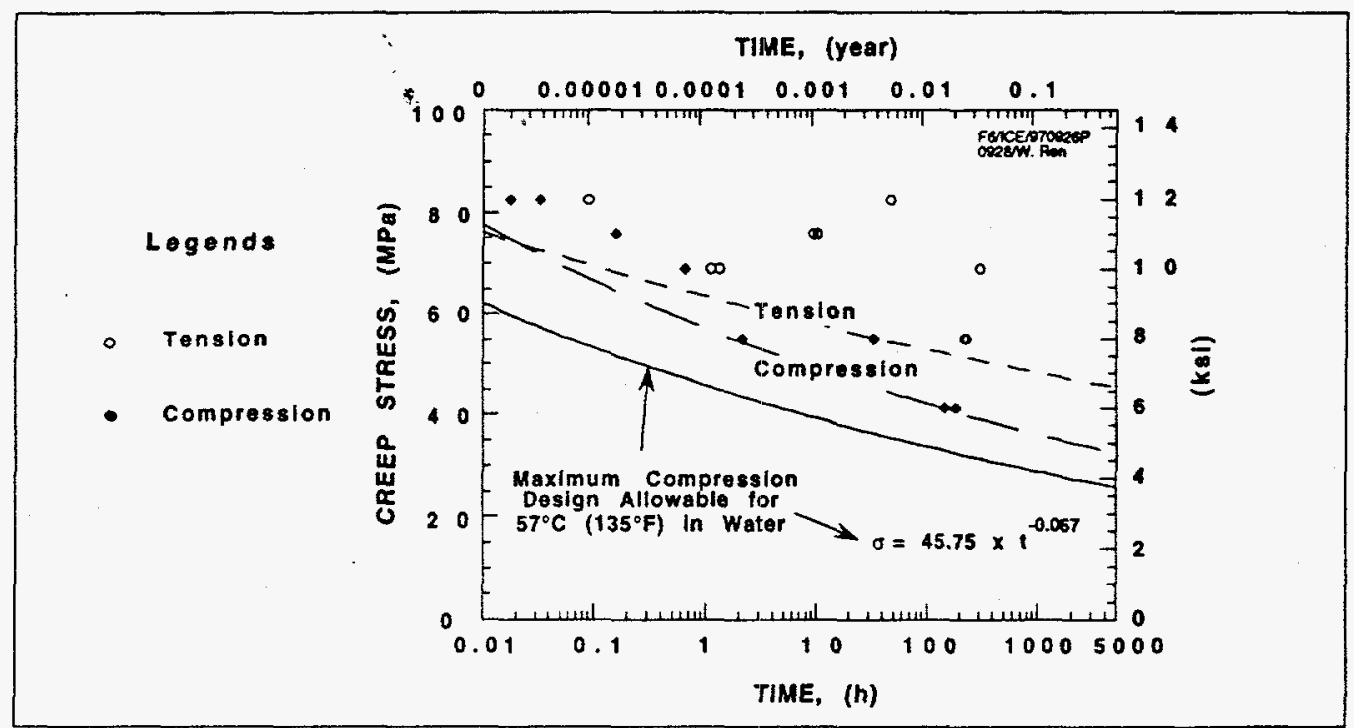

Figure 6. The no-rupture lines indicate that creep-rupture stress under compression is less than that under tension in water at $57^{\circ} \mathrm{C}\left(135^{\circ} \mathrm{F}\right)$. 
TABLE 1 THE PROPOSED STRESS REDUCTION FACTORS FOR SOME COMBINED ENVIRONMENTAL EFFECTS ARE BASED ON THE MAXIMUM STRESS ALLOWABLE STRESS CURVE FOR AIR/50\%RH AT $24^{\circ} \mathrm{C}\left(75^{\circ} \mathrm{F}\right)$.

\begin{tabular}{|c|c|c|c|c|c|c|c|c|c|}
\hline \multirow[b]{2}{*}{ Conditions } & \multicolumn{7}{|c|}{$\begin{array}{l}\text { Stress Reduction Factor for Specific } \\
\text { No-Rupture Time Limits (hour or year) }\end{array}$} & \multicolumn{2}{|c|}{ Range } \\
\hline & $\begin{array}{l}1000 \\
\text { hour }\end{array}$ & $\begin{array}{l}3000 \\
\text { hour }\end{array}$ & $\begin{array}{l}5000 \\
\text { hour }\end{array}$ & $\begin{array}{c}1 \\
\text { year }\end{array}$ & $\begin{array}{c}5 \\
\text { year }\end{array}$ & $\begin{array}{c}10 \\
\text { year }\end{array}$ & $\begin{array}{c}15 \\
\text { year }\end{array}$ & Min & $\operatorname{Max}$ \\
\hline $24^{\circ} \mathrm{C}\left(75^{\circ} \mathrm{F}\right) / \mathrm{Air}=50 \% \mathrm{RH}$ & 1.00 & 1.00 & 1.00 & 1.00 & 1.00 & 1.00 & 1.00 & 1.00 & 1.00 \\
\hline$-8^{\circ} \mathrm{C}\left(20^{\circ} \mathrm{F}\right) / \mathrm{Air}=50 \% \mathrm{RH}$ & 1.00 & 1.00 & 1.00 & 1.00 & 1.00 & 1.00 & 1.00 & 1.00 & 1.00 \\
\hline $57^{\circ} \mathrm{C}\left(135^{\circ} \mathrm{F}\right) /$ Air $=50 \% \mathrm{RH}$ & 0.99 & 0.99 & 0.99 & 0.99 & 0.99 & 0.99 & 0.99 & 0.99 & 0.99 \\
\hline $88^{\circ} \mathrm{C}\left(190^{\circ} \mathrm{F}\right) / \mathrm{Air}=50 \% \mathrm{RH}$ & 0.91 & 0.91 & 0.91 & - & - & - & - & 0.91 & 0.91 \\
\hline $121^{\circ} \mathrm{C}\left(250^{\circ} \mathrm{F}\right) /$ Air $=50 \% \mathrm{RH}$ & 0.65 & 0.65 & 0.64 & - & - & - & - & 0.64 & 0.65 \\
\hline $24^{\circ} \mathrm{C}\left(75^{\circ} \mathrm{F}\right) / \mathrm{Air}<10 \%$ & 1.11 & 1.11 & 1.11 & 1.11 & 1.11 & 1.11 & 1.11 & 1.11 & 1.11 \\
\hline $24^{\circ} \mathrm{C}\left(75^{\circ} \mathrm{F}\right) / \mathrm{Air}>90 \%$ & 0.68 & 0.65 & 0.63 & 0.61 & 0.56 & 0.55 & 0.53 & 0.53 & 0.68 \\
\hline $24^{\circ} \mathrm{C}\left(75^{\circ} \mathrm{F}\right) /$ Water $(\mathrm{Tn} \& \mathrm{Cm})$ & 0.54 & 0.52 & 0.51 & - & - & - & - & 0.51 & 0.54 \\
\hline $57^{\circ} \mathrm{C}\left(135^{\circ} \mathrm{F}\right) /$ water $(\mathrm{Tn})$ & 0.53 & 0.51 & 0.51 & - & - & - & - & 0.51 & 0.53 \\
\hline $57^{\circ} \mathrm{C}\left(135^{\circ} \mathrm{F}\right) /$ Water $(\mathrm{Cm})$ & 0.41 & 0.38 & 0.37 & - & - & - & - & 0.37 & 0.41 \\
\hline $88^{\circ} \mathrm{C}\left(190^{\circ} \mathrm{F}\right) /$ Water & 0.19 & 0.17 & 0.16 & - & - & - & - & 0.16 & 0.19 \\
\hline $24^{\circ} \mathrm{C}\left(75^{\circ} \mathrm{F}\right) / \mathrm{Motor}$ Vibration/Air & 0.92 & 0.90 & 0.89 & - & - & - & - & 0.89 & 0.92 \\
\hline $24^{\circ} \mathrm{C}\left(75^{\circ} \mathrm{F}\right) / \mathrm{Load}$ Cycling/Air & 0.44 & 0.40 & 0.38 & - & - & - & - & 0.38 & 0.44 \\
\hline $24^{\circ} \mathrm{C}\left(75^{\circ} \mathrm{F}\right) /$ Load Cycling/Water & 0.42 & 0.38 & 0.36 & - & - & - & - & 0.36 & 0.42 \\
\hline $24^{\circ} \mathrm{C}\left(75^{\circ} \mathrm{F}\right) / \mathrm{Brake}$ Fluid & 0.77 & 0.75 & 0.74 & 0.73 & 0.70 & 0.69 & 0.68 & 0.68 & 0.77 \\
\hline $24^{\circ} \mathrm{C}\left(75^{\circ} \mathrm{F}\right) /$ Used Motor Oil & 0.93 & 0.92 & 0.91 & 0.91 & 0.89 & 0.88 & 0.88 & 0.88 & 0.93 \\
\hline $24^{\circ} \mathrm{C}\left(75^{\circ} \mathrm{F}\right) /$ Sulfuric Acid & 0.19 & 0.17 & 0.16 & - & - & - & - & 0.16 & 0.19 \\
\hline
\end{tabular}

* $\quad \mathrm{Tn}=$ Tension, $\mathrm{Cm}=$ Compression.

Test results show that creep strength of the material under compression is comparable to that under tension in air $=50 \% \mathrm{RH}$ and water at $24^{\circ} \mathrm{C}\left(75^{\circ} \mathrm{F}\right)$, but becomes less than that under tension in water as temperature increases. Figure 6 gives the comparison of creep stress and rupture life in water at $57^{\circ} \mathrm{C}\left(135^{\circ} \mathrm{F}\right)$ under tension and compression. It is apparent that at a given stress, creep-rupture time is shortened under compression. Therefore, no-rupture line for compression was used to develop the proposed maximum design allowable stress curve and equation in Figure 6.

It should be pointed out that the above factors often work synergistically and have combined effects on the material. Some of the combined environmental effects on creep-rupture stress are presented in Table 1 as stress reduction factors, which are the ratios of the proposed maximum design allowable stress in a given condition to that in air $=50 \% \mathrm{RH}$ at $24^{\circ} \mathrm{C}\left(75^{\circ} \mathrm{F}\right)$. The proposed maximum design allowable stress equation for air $=50 \% \mathrm{RH}$ at $24^{\circ} \mathrm{C}\left(75^{\circ} \mathrm{F}\right)$ is given as $\sigma=75.93 \mathrm{t}^{-0.01}$. Note that the units for the proposed maximum design allowable stress equations throughout this paper are $\mathrm{MPa}$ for stress and hour for time, and the equations are valid for the same time limits indicated in Table 1 for various conditions.

It should also be pointed out that extrapolation was employed in developing the maximum design allowable stresses and stress reduction factors for certain time limits as listed in Table 1, and the extrapolation was based on the assumption that the material behaves as it did within the testing duration. The mechanical property 
changes which may happen during very long-term exposure to certain environments far beyond the test duration were not theoretically taken into consideration. However, for the time limits listed in Table 1, the effects of these possible changes are believed to be taken into account by the 0.8 safety factor.

\section{CONCLUSIONS}

1. Below $96.5 \mathrm{MPa}$ (14 $\mathrm{ksi}$ ), the creep strain is proportional to stress in air $=50 \% \mathrm{RH}$ at $24^{\circ} \mathrm{C}\left(75^{\circ} \mathrm{F}\right)$. Fracture occurs without obvious acceleration of the creep rate or local necking.

2. Increases in temperature and humidity decrease creep strength and rupture time.

3. At room temperature, creep-rupture stress decreases in the order of oil-based fluids (used motor oil and brake fluid), water and water-based fluids (salt water, windshield fluid and anti-freeze coolant) and battery acid (immerse and splatter).

4. Creep strength and rupture time can be reduced slightly by motor vibration but significantly by low frequency load cycling.

5. Creep-rupture stress under compression is comparable to that under tension in air $=50 \% \mathrm{RH}$ and water at $24^{\circ} \mathrm{C}\left(75^{\circ} \mathrm{F}\right)$, but less than that under tension in water at $57^{\circ} \mathrm{C}\left(135^{\circ} \mathrm{F}\right)$.

6. Propósed stress reduction factors have been developed for most commonly encountered automotive environments.

\section{REFERENCES}

1. Corum, J. M. Ruggles, R. L. Battiste, W. A. Simpson, H. E. McCoy and Y. J. Weitsman, 1996. "Durability of Composites in Automotive Structural Applications," in Annual Automotive Technology Development Customers Coordination Meeting, Vol. II: Automotive R\&D Poster Session, pp. 313-327.

2. Karger-Kocsis, J., 1991. "Environmental Stress Corrosion Behavior of Polyamides and Their Composites with Short Glass Fibers and Glass Swirl Mat," Polymer Bulletin, 26:123-130.

3. Karger-Kocsis, J. and Zs. Fejes-Kozma 1994. "Damage Zone Development and Failure Sequence in Glass Fiber Mat-Reinforced Polypropylene Under Static Loading Conditions," Mechanics of Composite Materials, 20(1):8-13.

4. Dearlove, T. J., D. L. Denton, E. M. Hagerman, D. Houston and S. N. Kakarala, 1994. "Development of Standardized Tests for an Automotive Structural Composites Database," in Proceedings of the 10th Annual ASM/ESD Advanced Composites Conference, pp. 555-566.

5. Robinson, D. N. August, 1997. "Representation of Creep for a Swirl-Mat GFRP Composite Under Various Stress, Temperature and Environmental Conditions," in Recommended Durability-Based Design Guide for Automotive Structural Composites, Oak Ridge National Laboratory, Oak Ridge, TN.

\section{ACKNOWLEDGMENTS}

The authors would like to thank Herb McCoy for his contributions to the preliminary work of this project. This research is sponsored by the U. S. Department of Energy, Assistant Secretary for Energy Efficiency and Renewable Energy, Office of Transportation Technologies, as part of the Advanced Automotive Materials Program, under contract DE-AC05-960R22464 with Lockheed Martin Energy Research Corporation. 